\title{
Editorial
}

\section{The concept of brand experience}

Journal of Brand Management (2009) 16, 417-419. doi:10.1057/bm.2009.5

My association with the Journal of Brand Management began in 1997 as an author with a rather strange article on SOOP branding. ${ }^{1}$

'SOOP,' you may ask. 'What is that?'

Here is how I began the abstract of this paper: 'SOOP branding - 'superficial outof-profundity" - focuses on the seemingly 'superficial' world of sensory, affective and creative experiences, which have been largely ignored by marketers and brand managers.' And I concluded by saying, 'SOOP branding thus proposes to treat consumers as living human beings with experiential needs rather than as rational price - and attribute-driven information processors.'

By now, in 2009, the term 'SOOP branding' is not well established in the branding literature. Nowadays, I and others refer to the approach outlined in this paper as 'experiential branding.' The term 'experiential branding,' on the other hand, has definitely caught on. In business practice, 'experience' is one of the 'hottest' movements. Numerous trade writings on experience have appeared over the years, ${ }^{2-4}$ and I have contributed a couple on my own. ${ }^{5,6}$ There are experience projects in a variety of industries, ranging from telecom to automotive to retailing businesses. Most importantly, companies have created new executive positions that are exclusively focused on managing customers' experiences with brands.

I firmly believe that the concept of brand experience captures the very essence of branding much more than analytically and cognitively oriented brand concepts such as brand equity, brand value, brand associations, brand attitudes and brand personality. What ultimately matters to consumers is whether brands can provide attractive experiences for them. To be sure, consumers are also looking for value, and for the right features, associations and brand personalities. But this is true for products as well. From brands, consumers expect something more distinct. They want something that engages their senses and touches their hearts. Something that excites or intrigues them. They want marketers to provide them with an experience. They are looking for something real and authentic, and not just ad slogans and messages that are supposed to target cognitions in their mind.

You can thus read my 1997 SOOP branding paper in this Journal as a passionate plea to go beyond mere functionality and utility, and to transcend the cognitive information processing paradigm by incorporating sensory, emotional and creative concepts into our thinking about brands.

I was not the first to argue that mainstream analytical and cognitive model, which define most of the marketing and branding literature, are incomplete. I was standing on the shoulders of giants. The giants in this case were my colleague at Columbia Business School Morris Holbrook and his co-author Elizabeth Hirshman who, years before, had written 
a highly influential paper on the "experiential aspects of consumption." Subtitle: 'Consumer fantasies, feelings, and fun.' I loved the paper but felt that the subsequent work, especially the interpretive work following it, was unnecessarily limiting; interpretive research applied the term 'experience' exclusively to special art phenomena and idiosyncratic hobbies such as jazz, art collecting and sky diving. My own interests and concerns were broader. I felt that the concept of experience could be applied to brands - all sort of brands in all sort of categories. To do so, however, we would need to go beyond Holbrook and Hirshman's (1982) paper.

What I felt we needed was a rigorous definition of experience, a reliable and valid measurement instrument, and a conceptual network of experience antecedents and consequences. We know a lot about brand equity and brand value, and we have elaborate models and measurements for brandassociation constructs such as brand personality. ${ }^{8}$ Yet, we know very little about how consumers experience a brand; how we can measure brand experiences; and whether brand experiences are simply an epiphenomenon or whether they can influence consumer behaviour. In sum, we need to develop the brand-experience construct conceptually, and I urge us all to do so.

That is not an easy task. Unlike other brand concepts and measurement scales, which we took from psychology and subsequently transferred to brand research, the concept of brand experience requires a broader, more inter-disciplinary research approach. Work on experience can be found in a variety of different fields, ranging from philosophy and cognitive science, to literature and the arts. We need to examine this literature for insights and apply it to the area of branding.

In a forthcoming paper, my co-authors and I have tried to take a first step. ${ }^{9}$ We defined brand experiences as subjective, internal consumer responses (sensations, feelings and cognitions) as well as behavioral responses evoked by brand-related stimuli that are part of a brand's design and identity, packaging, communications and environments.' We distinguished various experience dimensions (sensory, affective, intellectual and behavioural) and showed how these dimensions can be measured. We also showed that experiences can affect certain aspects of consumer behaviour (satisfaction and loyalty).

Yet, much more needs to be done to fully establish the concept in our field. One key question concerns the antecedents of experiences. How exactly can brand-related stimuli (names, logos, colors, shapes and so on) that are part of a brand's marketing evoke brand experiences? Or consider one particular marketing tool - events. We need to relate dimensions of the event (for example, entertainment, interactivity, faceto-face service) to dimensions of experience. Similar issues could be investigated for other marketing tools (for example, advertising, sales promotions, new media). For example, how do these tools evoke experiences? These are not just academic questions. Experience managers in companies urgently need answers to these questions to replace their intuitive guidelines with systematic planning tools.

Another key question concerns the consequences of brand experience: Are most brand experiences just epiphenomena - that is, when they occur they are just fun for consumers? Do they influence consumer behaviour only in the short term? Or can they have long-term effects? For example, can experiences build brand equity, or rather, customer equity, that is, customer lifetime value?

Finally, what is the relation between brand experience and other brand constructs? There has been an inflation in brand constructs and measurements over the years. In the paper mentioned earlier, we 
showed conceptually and empirically, that brand experiences are distinct from some key cognitive, motivational and affective constructs such as brand attitudes, brand involvement, brand attachment and customer delight. But clearly there must be some empirical relation between brand experience and motivational and emotional brand concepts, especially when we examine their impact on consumer behavior. What is that relation? Are certain concepts more basic or primary than others? Which ones are most useful for formulating brand strategy?

As these questions illustrate, research on brand experience offers a rich area of inquiry. Experience is a profound concept focused on one of the most important aspects of our lives: the seemingly superficial world of brands.

\section{REFERENCES}

(1) Schmitt, B. H. (1997) Superficial out of profundity: The branding of customer experiences. The Journal of Brand Management 5: 92-98.

(2) Pine II, J. B. and James, H. G. (1999) The Experience Economy: Work is Theatre and Every Business a Stage. Cambridge, MA: Harvard Business School Press.
(3) Shaw, C. and John, I. (2002) Building Great Customer Experiences. New York: Palgrave Macmillan.

(4) Smith, S. and Joe, W. (2002) Managing the Customer Experience: Turning Customers into Advocates. Upper Saddle River, NJ: Financial Times Prentice Hall.

(5) Schmitt, B. H. (1999) Experiential Marketing: How to Get Customers to Sense, Feel, Think, Act, Relate to Your Company and Brands. New York: The Free Press.

(6) Schmitt, B. H. (2003) Customer Experience Management. New York: Wiley.

(7) Holbrook, M. and Elizabeth, C. H. (1982) The experiential aspects of consumption: Consumer fantasies, feelings, and fun. Journal of Consumer Research 9(September): 132-140.

(8) Examples of papers in the Journal of Brand Management from this year alone include the following two papers: Raggio, R. D. and Robert, P. L. (2009) Chasing brand value: Fully leveraging brand equity to maximise brand value. Journal of Brand Management 16: 248-263, and Casidy, M.R., Yelena, T. and Alastair, A. (2009) The big five and brand personality: Investigating the impact of consumer personality on preferences towards particular brand personality. Journal of Brand Management 16: 234-247.

(9) Brakus, J. J., Schmitt, B. and Lia, Z. (forthcoming) Brand experience: What is it? How is it measured? Does it affect loyalty? Journal of Marketing 73(3): 52-68.

Bernd Schmitt

Center on Global Brand Leadership, Columbia Business School, New York, USA 